\title{
RURAL DEVELOPMENT IN SPARSELY POPULATED AREAS. VRANOV NA DYJÍ MICRO-REGION IN MORAVIA
}

\author{
Antonín Vaishar ${ }^{1}$, Milada Štastná ${ }^{2}$
}

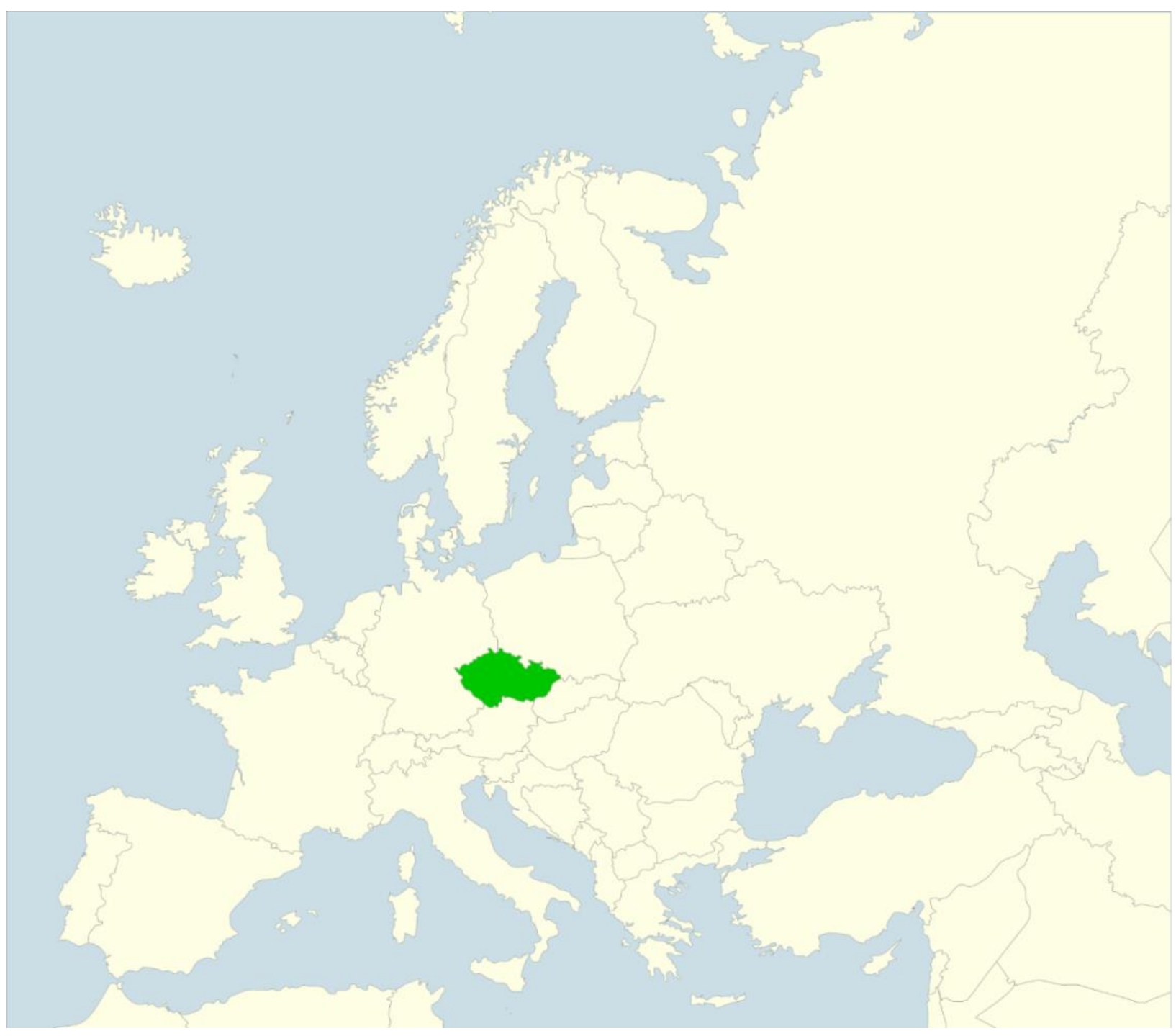

\footnotetext{
${ }^{1}$ Assoc. Prof. Dr. Antonín Vaishar, Department of Applied and Landscape Ecology, Mendel University in Brno, Czechia; e-mail: antonin.vaishar@mendelu.cz, ORCID: 0000-0003-3754-7600

2 Prof. Dr. Milada Št'astná, Department of Applied and Landscape Ecology, Mendel University in Brno, Czechia; e-mail: stastna@mendelu.cu, ORCID: 0000-0002-4507-6207
} 
Abstract: The article analyses the possibilities of development of one of the most peripheral micro-regions of Moravia on the basis of the theory of sustainability. It notes its aboveaverage focus on agriculture and tourism, which is linked to seasonality, lower education of the population, depopulation and higher unemployment. The settlement structure with predominantly very small villages conditions a worse infrastructure, which is partially balanced by a high-quality natural environment. Possible solutions are seen in the focus on qualitative development and support of social capital. The transition to post-productive development and counter-urbanization gives to regions of this type new opportunities associated with the development of housing and tourism.

Key Words: sustainable rural development, sparsely populated area, borderland periphery, qualitative aspects, Vranov nad Dyjí, Moravia

Souhrn: Článek analyzuje možnosti rozvoje jednoho z nejodlehlejších mikroregionů Moravy na bázi teorie udržitelnosti. Konstatuje jeho nadprůměrné zaměření na zemědělství a cestovní ruch, což je spojeno se sezónností, nižší vzdělaností obyvatel, depopulací a vyšší sezónně podmíněnou nezaměstnaností. Sídelní struktura s převažujícími velmi malými vesnicemi podmiňuje horší infrastrukturu, která je částečně vyrovnávána kvalitním přírodním prostředím. Možnosti řešení jsou spatřovány $v$ zaměření na kvalitativní rozvoj a podporu sociálního kapitálu. Přechod k postproduktivnímu vývoji a kontraurbanizace dávají regionům tohoto typu nové šance spojené s rozvojem bydlení a cestovního ruchu.

Klíčová slova: udržitelný rozvoj venkova, řídce osídlené oblasti, pohraniční periferie, kvalitativní aspekty, Vranov nad Dyjí, Morava

\section{Highlights:}

- The studied region shows all signs of remoteness

- The analysis of its sustainability shows tendencies of depopulation and seasonal unemployment

- Recommendations relate to a qualitative understanding of development

- The transition to a post-productive society increases the area's chances in developing tourism

\section{Introduction}

In European conditions, the countryside is often described as depopulating, with disappearing services and limited public transport with high unemployment. In fact, these characteristics relate at most to remote, sparsely populated countryside on the inner or border periphery. These areas are characterized by great distance from regional centres, absence of full-fledged small towns within reach, often difficult transport conditions, limited resources of raw materials, people and capital. Their unfavourable conditions for agriculture are gradually changing into a favourable situation in terms of tourism development. The growth of tourism is mostly proposed as a universal means of rural development in sparsely populated areas, without examining the real conditions for the success of such a focus.

At the same time, the development of sparsely populated rural areas is important for two main reasons. The first is to ensure dignified living conditions for the locals, who in turn maintain their settlements, the landscape and its genius loci. The second reason is to maintain cohesion in the development of regions, the country and Europe. If the social and economic disparities between sparsely populated and metropolitan regions widen beyond tolerable levels, 
the motivation of the people of the periphery to strive for anything will disappear and sparsely populated territory could fall into chaos.

The aim of this paper is to analyse the real problems of sparsely populated areas in the current period on the example of the most problematic border micro-region of the South Moravian Region. Rural development options with an emphasis on cultural tourism will also be discussed.

\section{Sparsely populated areas}

Le Tourneau (2020) emphasizes the specificity of the scientific approach to sparsely populated areas. The problems of sparsely populated areas are, of course, discussed mainly in countries with a generally low population density. In Europe, this mainly concerns Scandinavia, the European part of Russia (e.g. Carson, Brouder and de la Barre, 2017), but also some areas of the inner periphery in Spain, France and Italy. In Central European conditions, of course, these are relatively sparsely populated areas on the local level. Few show population density values below the European average. In the European Union, sparsely shared territories belong to territories with specific geographical features, together with islands and mountain areas (Giordano, 2016). As such, they are the subject of specific support under the European Regional Development Fund. Maintaining cohesion is a key issue (Muravska, Aprāns and Dahr, 2016).

Sparse settlement is usually associated with the idea of the periphery (Marada et al., 2006) as a result of the geographical polarization of space. The concept of the centre - the periphery, or the city - the hinterland implies that the population density decreases from the centre to the periphery - if we understand the periphery as a function of distance from the centre (Kubeš and Chvojková, 2020). However, it is always necessary to work with a specific centre-periphery relationship, because in densely populated areas, also the periphery can be densely populated. In addition, with the increasing transport and digital mobility of the population, the essence of peripherality is also modified (Copus, 2001). The role of distance is declining and sparsely populated regions are beginning to be sought after by people who strive for a less stressful environment and proximity to nature. However, these people remain in physical and digital contact with the centres. In such cases, therefore, there can be no question of peripherality in the sense of underdeveloped areas.

Typical peripheral problems tend to be associated with a low level or even deterioration of the quality of human capital (Wójcik et al., 2018), measured for example, by formal education or the level of entrepreneurship. It is a state where educated and active people migrate to important centres (Vaishar and Pavlü, 2018).

The main problems of sparsely shared areas are depopulation, poor transport accessibility especially by public transport (Berg and Ihlström, 2019), problems with the provision of services of public interest, such as health care, education, social care (Wilson and Copus, 2018). Add to this, the lack of local capital and, due to the remoteness, the reluctance of investors from other regions to invest in such an area. On the other hand, sparsely populated areas can be a convenient location for small and medium-sized enterprises within the green economy (Aarstad and Jakobsen, 2020). However, it is necessary to abandon the long-held notion that development is defined quantitatively.

Depopulation reduces population density and thus exacerbates the problems of sparsely populated areas (Burneika, Daugirdas and Ubarevičiené, 2014, Delgado Viñas, 2019). Some hopes associated with the placement of foreign migrants in sparsely populated areas prove to be odd due to better access to employment opportunities in metropolitan areas (Manakou, 2018). After all, the question is whether this way of dealing with emigration from sparsely populated areas would be desirable. On the other hand, natural trends in naturbanization are beginning to emerge, which in some cases are beginning to slow down depopulation tendencies.

On the other hand, due to the low population density, there is less pressure in these areas on the landscape and the environment, which is usually of better quality. This fact represents a certain potential for the development of tourism, the importance of which will grow in the postindustrial economy (Carson, Carson and Lundmark, 2017). However, the necessary tourist 
infrastructure is not always available in sparsely populated areas. Tourism in sparsely populated areas usually offers mainly the consumption of natural heritage (Svensson, 2009), possibly local folklore values (Leu, 2018) or some special sorts of tourism like hunting, fishing or eco-tourism.

The key to solving problems in sparsely populated areas is sometimes seen in smart technologies (Sörvik et al., 2019) or in the tourism development (Lundmark, Eduardson and Karlsson, 2014), eventually through a special training models (Diaz-Puente, Gallego Moreno and Zamorano, 2012) and labour mobility for longer distances (Sandow, 2008). Syssner a Meijer (2020) emphasize that specific planning procedures should be used for sparsely populated areas.

\section{Methodology and the area under investigation}

The concept of sparsely populated areas is clearly related to population density. This most often means the total population per unit area. What population density defines sparsely populated areas? The average World population density is 44 people $/ \mathrm{km}^{2}$. In the European Union, the population density is 112 persons $/ \mathrm{km}^{2}$, while (apart from the mini-states) it peaks in the Benelux countries (Netherlands 422, Belgium 376) and in the United Kingdom (280 persons per $\mathrm{km}^{2}$ ), with a minimum in Scandinavia (Finland 16, Norway 17, Sweden 23 persons $/ \mathrm{km}^{2}$ ). The population density of the Czech Republic is slightly above average (135 inhabitants per km²).

For larger states or countries with very different geographical conditions, the differences in population density are significantly higher. Although Czechia does not belong to the above category, regions (at the NUTS 3 level) with significantly lower population density can also be singled out on its territory. Average population density under 100 persons per $\mathrm{km}^{2}$ is recorded in Karlovarský, Plzeňský, Jihočeský and Vysočina regions. The South Moravian Region even has an above-average population density of 165 persons $/ \mathrm{km}^{2}$. Nevertheless, even in its territory there are sparsely populated areas. Especially in the catchment areas in the south-western part of the region (Moravský Krumlov, Pohořelice, Znojmo) the population density falls below 75 persons $/ \mathrm{km}^{2}$. Other areas with low population density could be found in the mountain areas of the South Bohemian and Pilsen regions.

Even lower population density can be observed in peripheral functional micro-regions. By far the lowest population density occurs in the Vranov nad Dyji microregion (23 persons $\left./ \mathrm{km}^{2}\right)$. This is followed by the micro-regions of Hrušovany nad Jevišovkou (57), Miroslav (63) and Velká nad Veličkou (64 inhabitants per $\mathrm{km}^{2}$ ). It is clear that the micro-region Vranov nad Dyjí is the area with far lowest population density in the South-Moravian region. This is an exceptionally low population density, which entitles us to include the Vranov region among sparsely populated areas in the European context.

In the analysis of the development possibilities of sparsely populated areas, we used the concept of sustainable development in its three dimensions - economic, social and environmental. Indicators and methodology for the analysis of problems of sparsely populated areas were proposed, for example, by Stepanova et al. (2020) on the example of the Russian Arctic regions. The work used mainly geographical methods, especially the analysis of statistical data, knowledge from field research (Vaishar et al., 2000), analysis of secondary sources. 


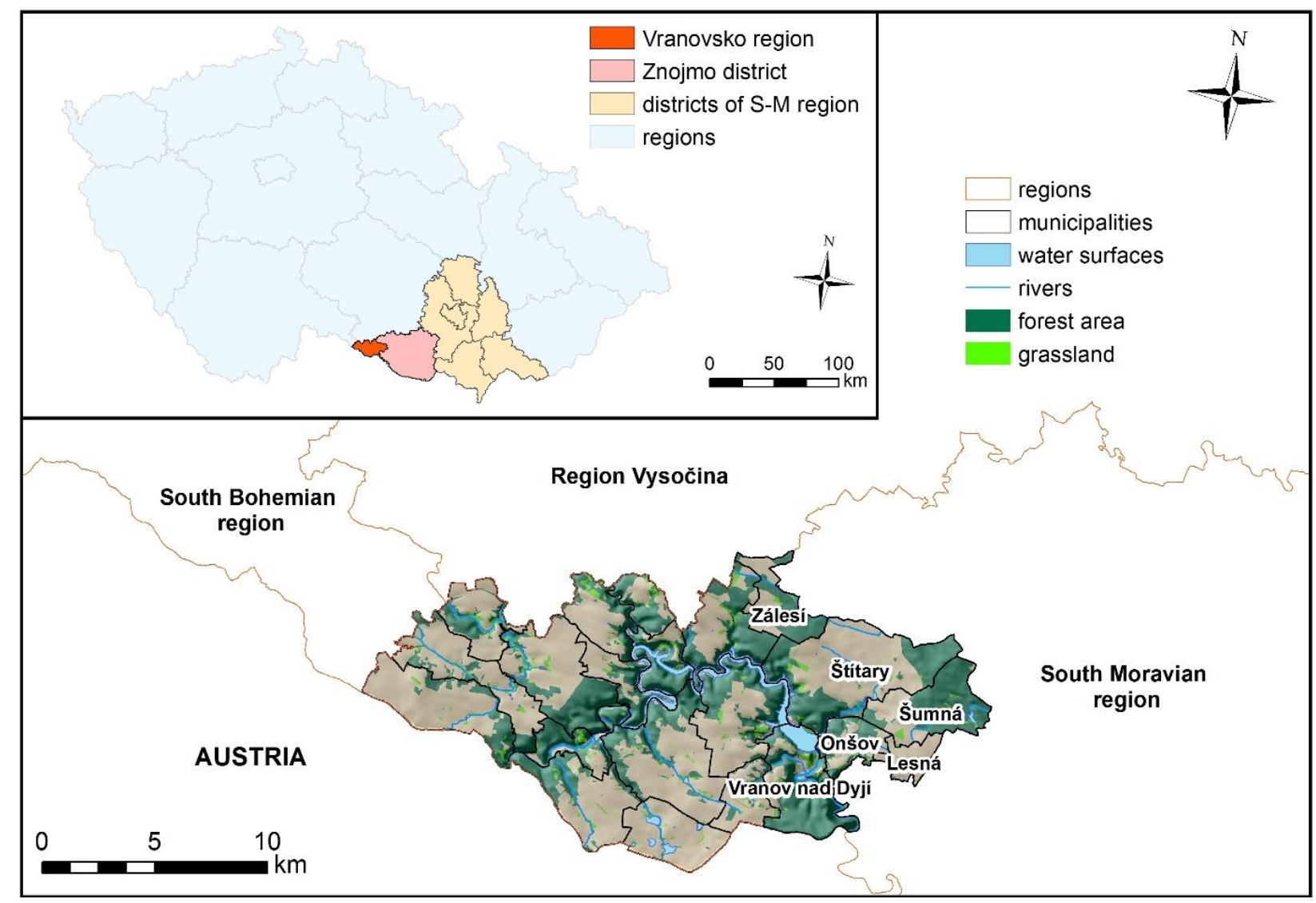

Fig 1. Area under study. Drawn by J. Brychta

The area under study is situated in South-Western Moravia on the border with Austria and not far from the historical border with Bohemia. The main natural value is the deeply sunken meandering valley of the river Dyje, in the part of which the Dyje National Park was declared in 1991. The national park represents an exceptionally well-preserved example of the landscape of a river valley in the hilly stage of Central Europe. The Dyje canyon creates a unique river phenomenon with numerous meanders, deeply cut valleys of side tributaries, various rock shapes, rocky seas and rocky walls. Most similar river valleys in Central Europe have been modified by the construction of dams, roads and recreational facilities. In the case of the Vranov region, the inaccessibility of the territory in terms of terrain and political barrier played a role. Geomorphologically, the territory belongs to Bítovská vrchovina uplands. Flat surfaces are covered mostly by fields, while steep scales are reportedly forested (Demek et al., 1987).

Traffic remoteness is one of the main factors in the marginality of the micro-region. The area is served only by roads of $2^{\text {nd }}$ and $3^{\text {rd }}$ class. The construction condition of these roads is neglected in many sections. In the busiest sections, the traffic intensity slightly exceeds 3,500 vehicles in 24 hours $^{3}$. The micro-region is touched by one regional railway line with a single stop in the village of Šumná.

\footnotetext{
${ }^{3}$ National Traffic Census 2016. Prague: Directorate of Roads and Motorways.
} 
The settlement and administrative structure is highly fragmented. On the area of $225.9 \mathrm{~km}^{2}$, there are 25 villages in the micro-region, which are integrated into 22 municipalities. The average distance between villages is $3 \mathrm{~km}$. There is no city or large village (which would have over a thousand inhabitants). The settlement structure consists of three medium-sized villages, including Vranov nad Dyjí, four small villages and 18 very small villages with less than 200 inhabitants, ten of which have less than a hundred inhabitants. The centre is Vranov nad Dyji (816 inhabitants, 2019), which is the seat of the authorized municipal office ${ }^{4}$ for the entire microregion. The Znojmo Municipal Authority has extended competencies for the Vranov region. Vranov is not able to integrate the whole micro-region, however, there is no other centre neither in the area, nor in the closest surroundings. This is one of the causes of the peripherality of the area.

The original Slavic settlement of the region was agricultural. Several castles were built on the border between Moravia and Austria, serving both for defence and for attacks on neighbouring countries. The centre of feudal administration was Bitov Castle. In the $12^{\text {th }}$ and $13^{\text {th }}$ centuries, colonists from Austria came to the sparsely populated area at the invitation of the Czech kings. The German-speaking population became dominant after the Thirty Years' War. After 1848, the administrative centre was shifted to Vranov. At the beginning of the twentieth century, the main enterprise of the Vranov region was a large farm, which farmed on 5.5 thousand hectares of land, mostly forest. The economic structure was complemented by the production of earthenware, wood processing, later silk products and handicrafts.

The establishment of Czechoslovakia in 1918 was not welcomed by the local Germans. They tried to join the internationally unrecognized unit of German South Moravia, which had no hope of success due to the defeat of Germany and Austria-Hungary in the war. The contract of St. Germain confirmed the region's affiliation with Czechoslovakia. The emergence of a standard state border had negative economic consequences, as it severed trade relations with settlements on the Austrian side. The economy and landscape of the Vranov region were significantly affected by the construction of the Vranov water reservoir, which was completed in 1933.

Before World War II, the vast majority of the population were ethnic Germans. After the Munich Agreement, most Czechs, Jews and German anti-fascists left. After the liberation in 1945, on the other hand, virtually all Germans were expelled, initially in a wild, later organized expulsion. The original Czech inhabitants returned to their places and also the new settlers from the interior came. After the failures of unified agricultural cooperatives, the Lesná State Farm was created. The wood was processed by the South Moravian Timber Plant Uherčice. A branch of the electrical engineering company Tesla Holešovice was established in Vranov. The area was at the Iron Curtain. Politically unreliable residents had to leave. The movement of people was restricted and controlled. This limited the recreational use of the area but at the same time preserved natural values.

The historical development can be illustrated on the population development graph (Figure 2). The economic base of the micro-region was originally based on primary activities - agriculture and forestry, or on the processing of local resources in small businesses (brewery, brickyard, mills). Major companies were the ceramics factory, which, however, ceased to exist after 1918 and later the hydro-power plant. The industry was introduced only within the so-called socialist industrialization, when several branches of companies from the interior were established here. These branches were closed first after 1989. A significant change was brought about by the construction of the Vranov dam on the Dyje. Its original purpose was to regulate flood waves on the Dyje, irrigation and electricity generation. But as early as 1934, tourism began to develop, which is probably the most important function of the water work today.

\footnotetext{
4 The administrative reform after 1990 led to the abolition of district offices, the creation of large regions and the separation of many previously integrated municipalities from their central parts. This created a large gap between very small municipalities and large regions without an intermediate stage. At the same time, it was not effective for municipalities with several dozen inhabitants to create professional administrative bodies. Therefore, a non-standard solution was adopted, where small municipalities are formally independent, but the professional powers for them are provided by authorized municipal authorities and municipal authorities with extended powers.
} 


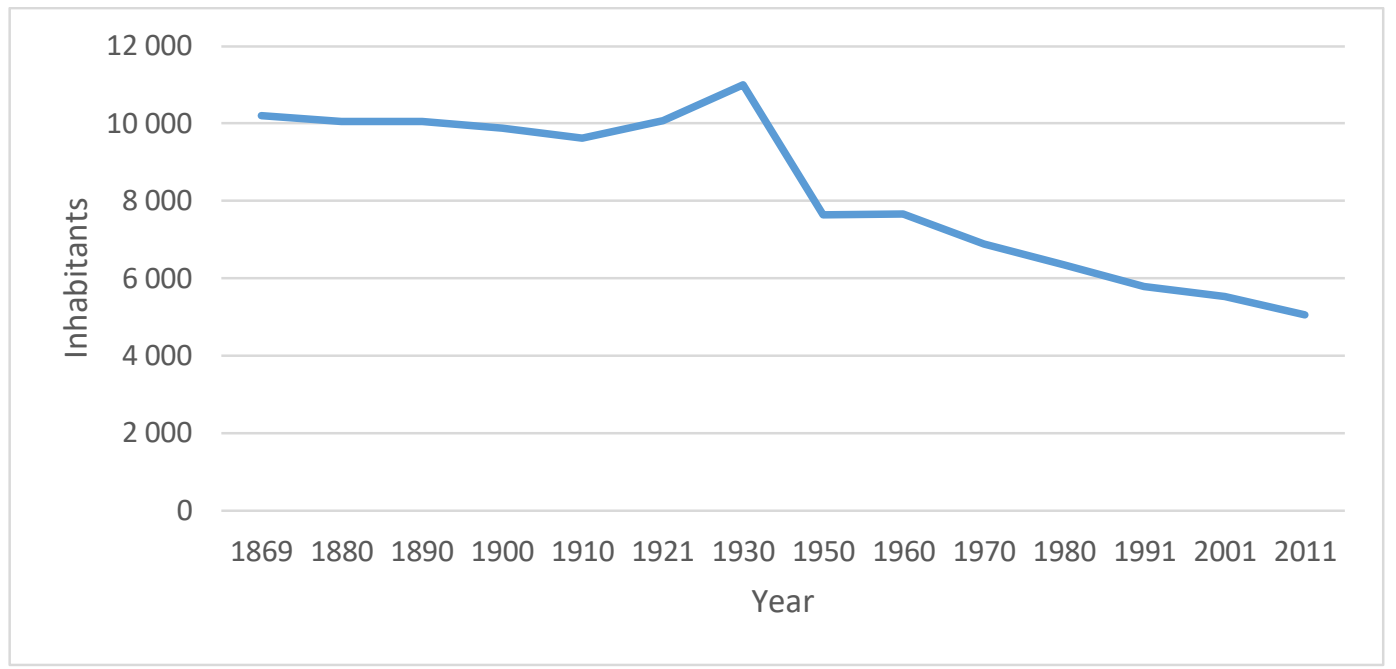

Fig 2. Population development in the region under study 1869-2011. Source: Historický lexikon, Prague, Czech Statistical Office. Own elaboration

The significant decline of the area dates back to World War II. At first, the vast majority of Germans, who made up the majority of the population before the war, were displaced. These inhabitants were never completely replaced. Moreover, the micro-region became a border that was part of the Iron Curtain. The exchange of inhabitants on an ethnic basis meant the severance of the population's relationship with the land, municipalities, the region and with each other. In addition, a social experiment was carried out on the settled border to prevent the restoration of the middle class. One of the results is a stable trend of population decline since 1960.

Developments after 1989 brought the opening of the state border, however, the neighbouring Lower Austrian region of Waldviertel is one of the least developed regions of the neighbouring country and no significant development impulses could be expected from there ${ }^{5}$. On the other hand, the defence components of the state border left and most of the state support for industry, agriculture and the social system disappeared. This resulted in further marginalization of the territory. A certain turnaround is signalled by the transition to a post-productive economy, which means, among other things, the development of tourism and services.

\section{Results}

\subsection{Economic Development}

In the 2011 census, a highly above-average $11.8 \%$ of employees were employed in agriculture and forestry, $44 \%$ in industry and only $44.2 \%$ in services. At the same time, $34.4 \%$ of employees went to work outside the municipality of their permanent residence. The district town Znojmo is the main target of the commuting. In 2019, 536 economic entities were registered in the microregion, which developed economic activity. Of these, $30.6 \%$ did business in industry and construction, $21.1 \%$ in agriculture and forestry, $12.9 \%$ in trade, repair and transport, $11 \%$ in accommodation, food and beverage service activities. Thus, the micro-region showed aboveaverage entrepreneurship in primary activities and tourism services.

Although agriculture and tourism belong to different sectors of the economy, they nevertheless show a number of important common features that affect the social system of the micro-region. These are highly seasonal sectors, where significant fluctuations in employment can be expected during the year. These are sectors that do not require a highly skilled workforce. Both sectors are among the activities with the lowest average wages. On the other hand, these sectors are less subject to cyclical crisis developments and, as it turns out, are also less affected by the COVID 19 pandemic, so that in certain circumstances, they may be a stabilizing element of the local economy.

\footnotetext{
${ }^{5}$ The population number of neighbouring Austrian municipalities Drossendorf and Langau has decreased from 3,563 to 1,875 persons between 1939 and 2014 .
} 


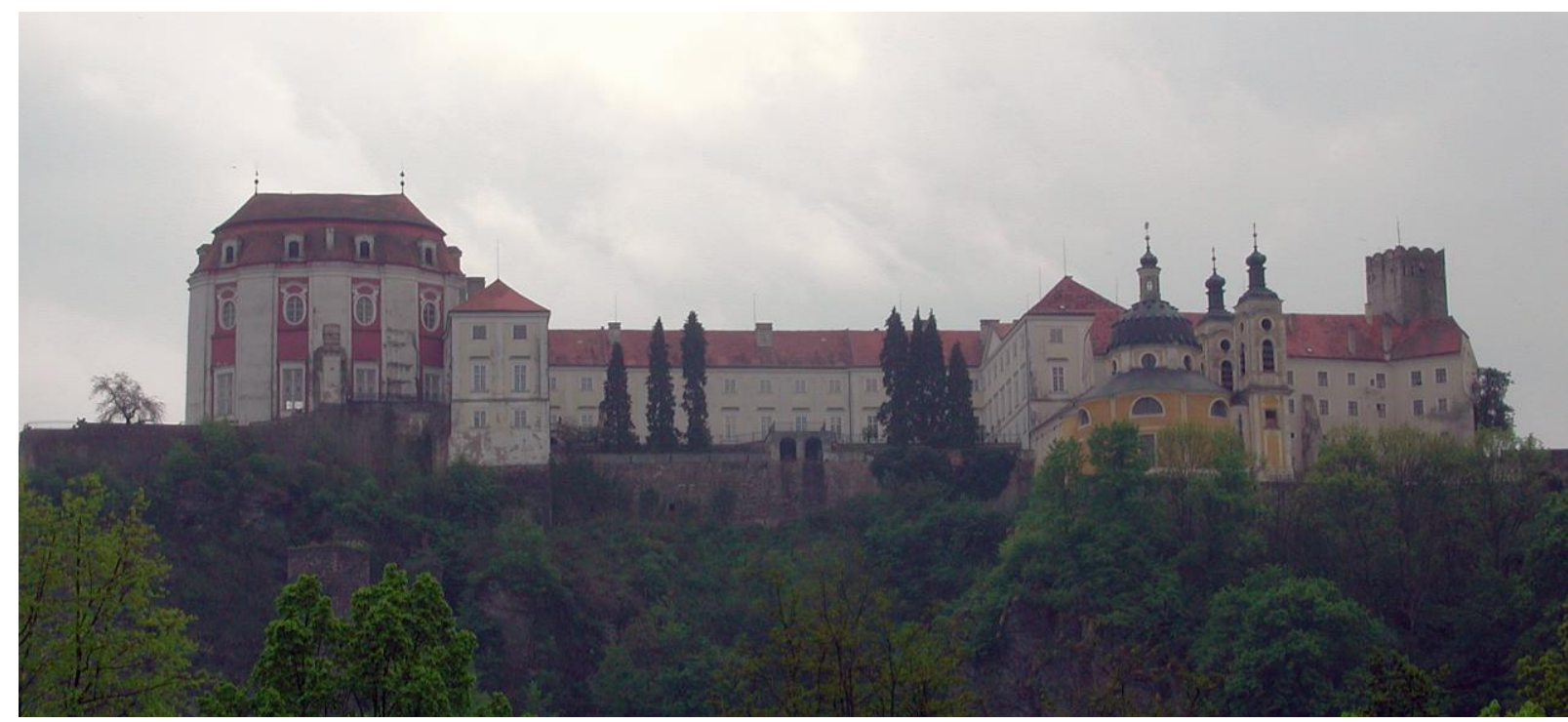

Fig 3. Vranov nad Dyji: the chateau. Photo authors

The most important companies in the area are agricultural cooperatives and tourism facilities. The prices of agricultural land for the calculation of land tax ${ }^{6}$ in the micro-region are on average values (usually between 6 and $11 \mathrm{CZK}$ per $\mathrm{m}^{2}$ ). The main production entities in the micro-region are three agricultural entities: Agriculture cooperative Korolupy (40 employee), Agricultural cooperative Petřín (30 employee) and Agro Uherčice, Ltd. (20 employee). These entities are also engaged in other activities in the field of road transport, waste disposal, trade in agricultural commodities, handicrafts and services and thus represent relatively complex employers. Production activities are also represented by small enterprises in the sphere of handicraft production; most of them are natural persons.

The second important business sector is tourism, which is mainly associated with localities adjacent to the Vranov water reservoir. The Camping Vranov Beach (60 employee) followed by Karel Podzimek Co. (50 employee) are the main employers within the tourism industry. Both of them have seasonal character. In addition to the water reservoir with shipping, the Vranov microregion has a number of other attractions. These are architectural monuments, the most important of which are Vranov Chateau, Bítov Castle and a number of ruins, as well as natural attractions. The micro-region is adjacent to the Podyji National Park and its Austrian counterpart. Nearby is also the Iron Curtain Museum, several light fortifications from the period before the Second World War, the Museum of Automobiles in Bítov or the Museum of Motorcycles in Lesná.

In 2019, there were 50 accommodation facilities in the area with 2,923 beds, which accommodated 57,400 guests, of which 6,007 were from abroad. The total number of overnight stays was $197,309^{7}$. The number of guests therefore exceeded the number of permanent residents by 11 times. There are 2.5 visitors per $\mathrm{km}^{2}$. The share of foreign visitors was only $10 \%$, which, however, caused less dependence on international tourism in the covid pandemic in 2020. The average number of overnight stays per visitor is 3.4 nights. However, there are also optional visitors in the area, staying in Brno or Znojmo. To the accommodation capacities, it is necessary to add another 525 unoccupied flats used for recreation. Additionally, Kubeš (2011) estimated the number of cottages in the vicinity of the Vranov water reservoir for 2,823 . Recently, some of these cottages have entered the tourism market in the form of short-term seasonal rentals. Thus, the number of beds for second housing crosses 10,000 for sure.

\footnotetext{
${ }^{6}$ Decree of the Ministry of Agriculture of the Czech Republic No. 288/2018 Coll. The market price may differ significantly from the official price.

7 Public database. Prague: Czech Statistical Office
} 


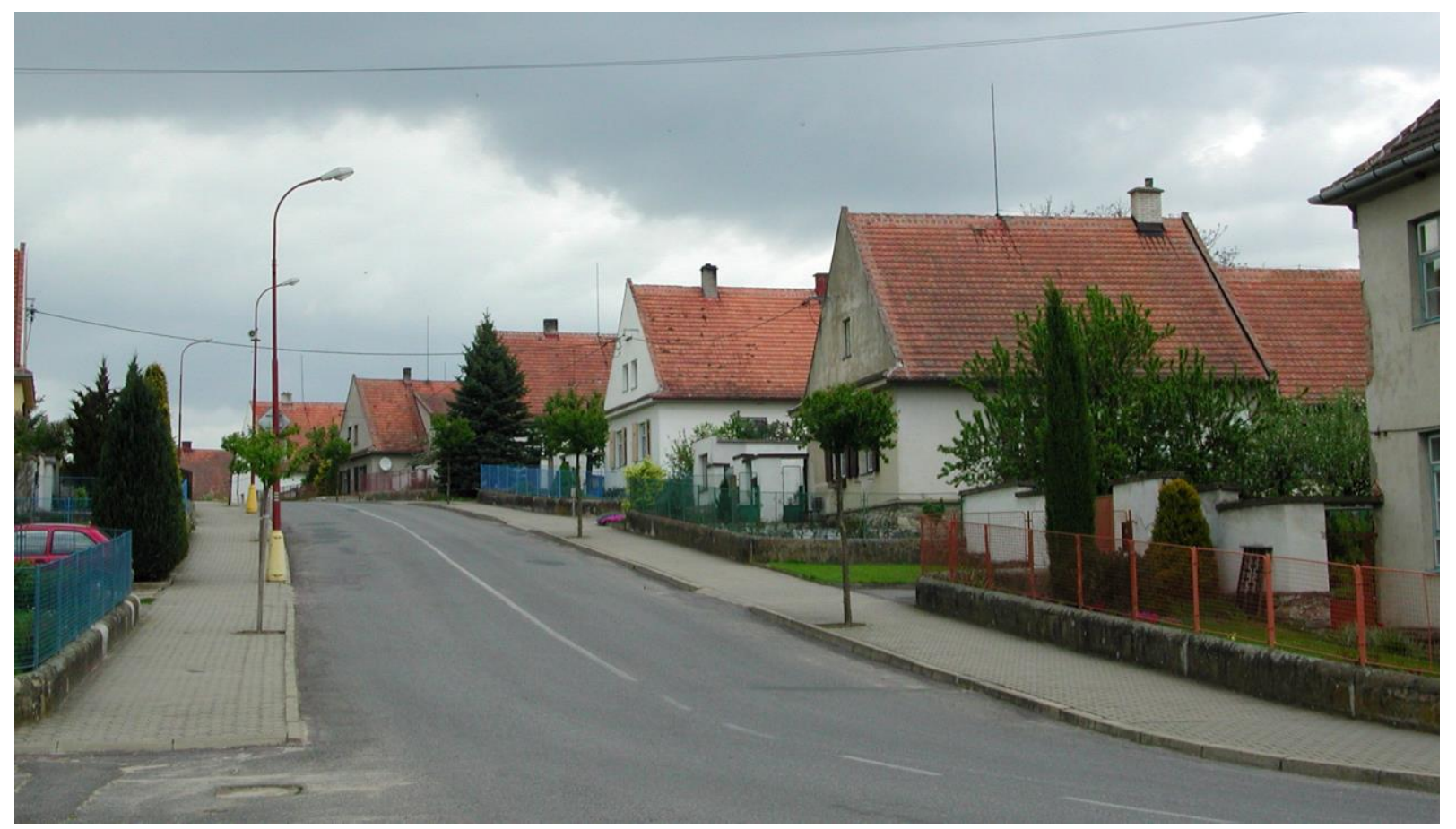

Fig 4. Village Bitov was constructed in the 1930s instead of the village of the same name, which was flooded by the Vranov reservoir. Photo authors

\subsection{Social and Demographic Development}

We chose the educational structure as an indicator of the social structure of the population. According to the 2011 census, in the Vranov nad Dyji micro-region, $0.8 \%$ of the population over the age of 15 was without education, $27.1 \%$ of the population with basic (including incomplete) education, $40.9 \%$ of the population is trained, $18.8 \%$ have a high school diploma and $8.1 \%$ have a post-secondary education. Compared to the national data, the studied region has a significantly higher share of the population with basic education and apprentices (68 vs. 51\%) and a significantly lower share of people with a high school diploma and higher education. This results in a significantly lower level of human capital.

The balance of population development over the last thirty years is shown in Fig. 5 . In the first half of the 1990s, the micro-region was characterized by a negative balance of migration (following trends in rural-urban migration), which was partially offset by natural population growth (perhaps due to a still young population acquired by immigration after World War II).

However, from about 1998 onwards, natural population decline began to prevail, probably due to aging. On the contrary, the negative migration balance is declining, until recently in some years the number of immigrants even outweighs the number of emigrants. The reason consists probably in post-productive changes in Czech society. However, it is not yet possible to speak of a stable trend. The question is the age structure of migrants. In the case of young families, this could have a positive impact on natural movement; if they are mostly in the elderly, aging will continue with all the consequences.

Changes in migratory flows are one of the results of the post-productive development of society. In the past, migration prevailed for work that went to cities and other job centres. Today, the quality of life is increasingly appearing among the motives for migration. For part of the population, this means living in a quiet environment closer to nature (Popjaková, Danielová and Valešková, 2018). The second reason is economic and organizational. In the socialist period, state and cooperative construction was massively supported in towns and central municipalities, while in non-central settlements it was rather administratively hindered. Support for the construction of housing estates ended around 1994. Without state support, it is extremely difficult to obtain housing in more attractive cities, even for members of the middle classes. Conversely, the cost of living in cities is rising and that is why some people are moving to rural 
areas. Sometimes they return to the houses they inherited from their ancestors, other times they adapt the original second homes to permanent living. In addition, building plots are usually available at the border.

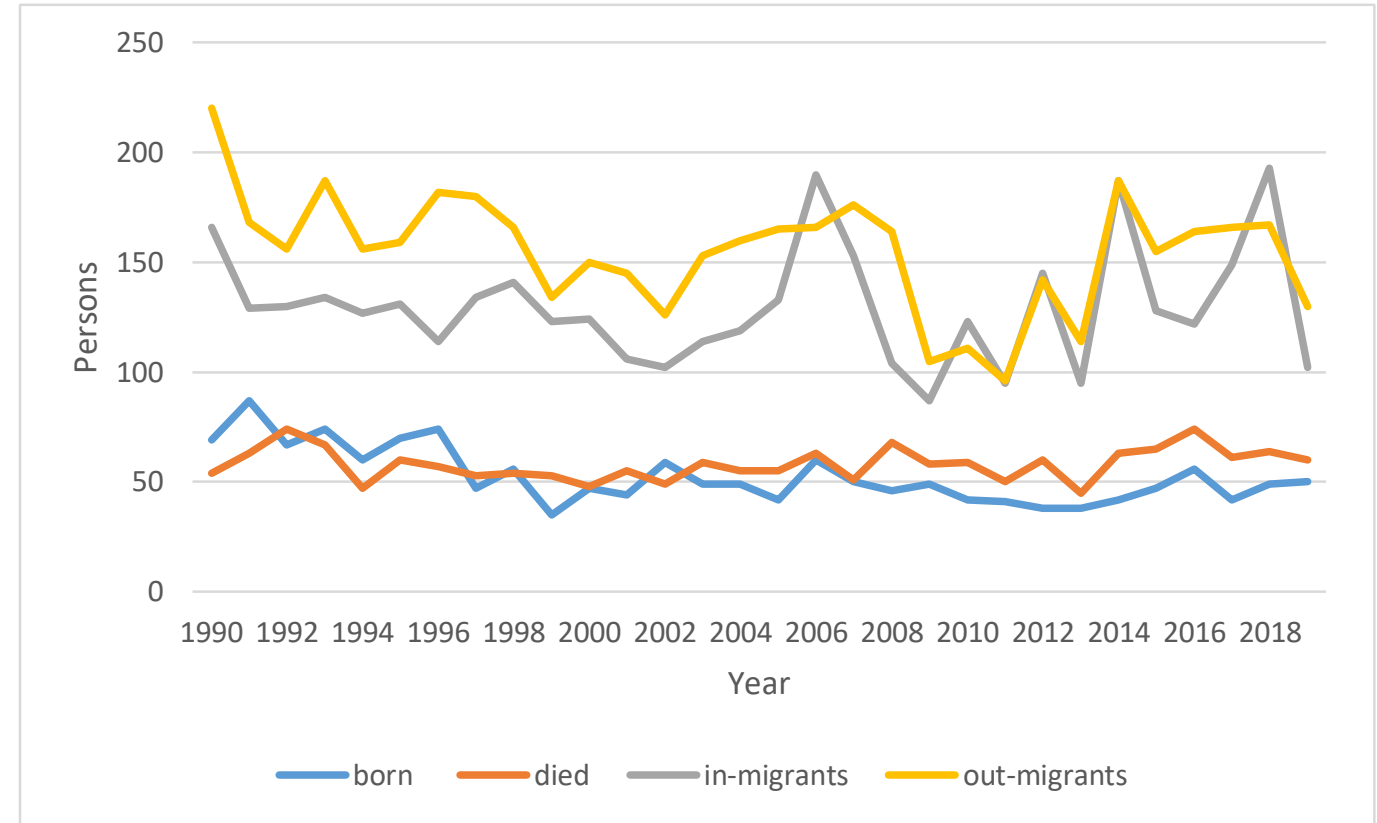

Fig 5. Population balances in the region under study 1990-2019. Source: Database of demographic data for municipalities in the Czech Republic. Prague: Czech Statistical Office. Own processing

At the end of $2019,13.5 \%$ of children under the age of $15,65.3 \%$ of the population of economically active age and $21.2 \%$ of seniors over the age of 65 lived in the Vranov region. This age structure is only slightly worse than the national structure, which contains $19.9 \%$ of seniors.

Another aspect of social sustainability is employment (Fig. 6). The micro-region under study has a relatively high unemployment rate. The main reason is probably the difficult commuting conditions, when mainly from the western part of the territory, the job centres are difficult to reach. Another aspect is the clear seasonal impact on the local labour market, which corresponds to an above-average share of job opportunities in agriculture and tourism. In the summer season, unemployment falls to acceptable levels, while in the winter months, it rises to ten percent. It follows that some households live on a combination of summer employment and winter social benefits.

Insufficient or even disappearing basic social infrastructure can be a problem, especially for very small settlements. Inadequate services are the result of a lack of customers who saturate their operations, either due to an absolute shortage (few children to keep school), the transition to online services (post offices) or the high mobility of the population, which results in their ability to gain access to services in better equipped centres. $60.4 \%$ of the micro-region's population lives in municipalities without a post office, $60.3 \%$ of the population lives in municipalities without a doctor and $51 \%$ in the municipalities without a school. Access to shops and restaurants was not monitored for their rapid changes and seasonality.

Due to the remoteness of the area, the current problem is the social exclusion of people who are not mobile through individual transport. Public transport in the area is organized through the Integrated Transport System of the South Moravian Region. This system provides a minimum of six pairs of connections on weekdays and three pairs of connections on weekends and holidays for all inhabited places in the region. This frequency can be considered sufficient. However, the frequency does not address the commute time, which exceeds 30 minutes, especially in the western tip of the territory. At the same time, the accessibility of major centres is even worse. The absence of rail transport in most areas is also a problem. 


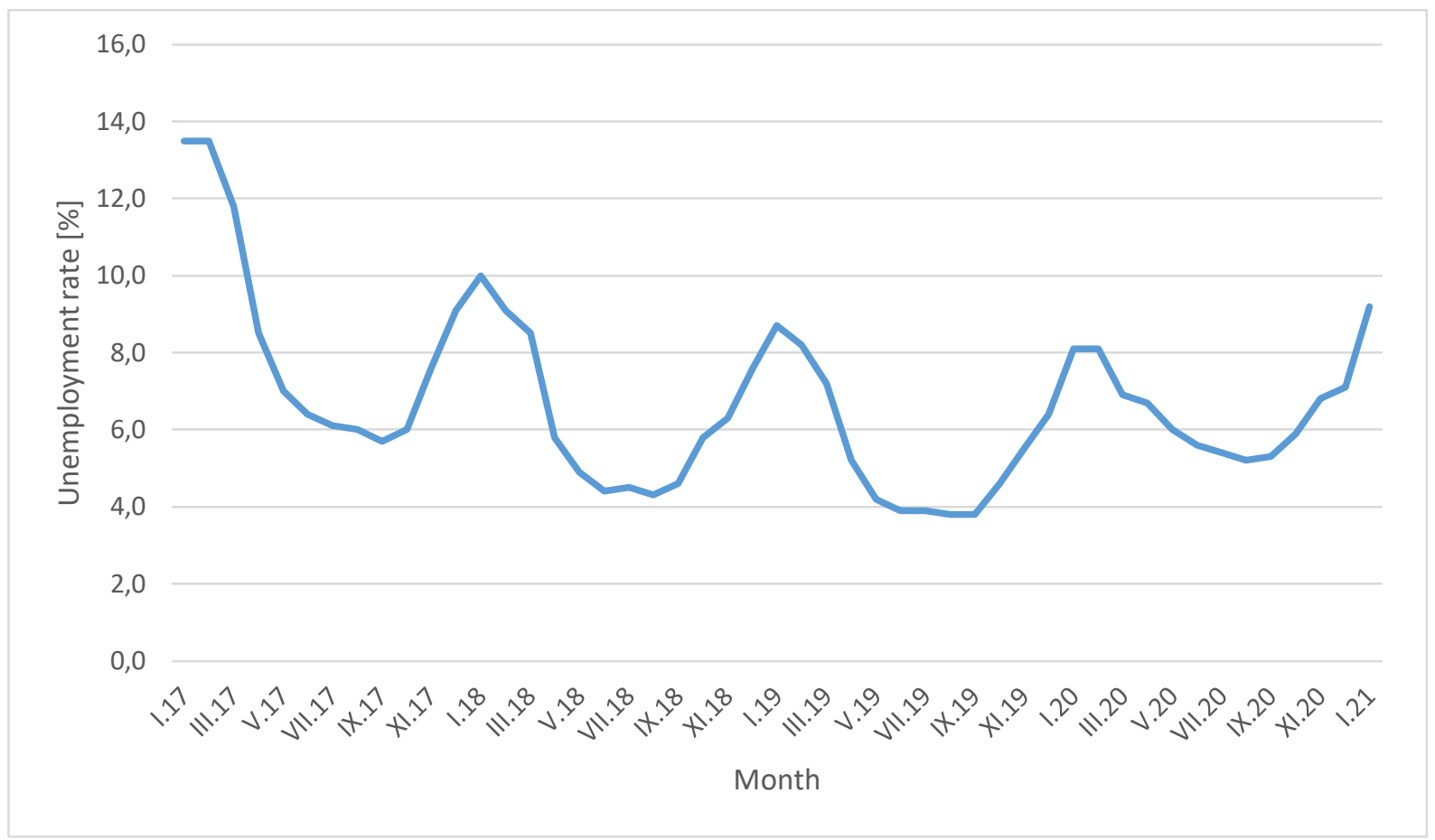

Fig 6. Unemployment rate 2017-2020. Source: Ministry of Labour and Social Affairs of the Czech Republic. Own elaboration

In the mid-1990s, a sociological survey was conducted in a region extended by the adjacent area of Jemnice in the Vysočina region (Vaishar, Kallabová and Zapletalová, 2000). The survey was attended by 710 parents and grandparents of primary school pupils in the region, of which 259 in the municipalities of our Vranov region. Among the respondents, the age categories 30 to 40 and 60 and over prevailed. $18.5 \%$ of the population considered moving out of the micro-region. If they intended to stay, housing was the decisive argument. $38.6 \%$ of respondents are worried about work. In case of job loss, $35.9 \%$ of people are willing to move out, $15.1 \%$ would try to start a business. Of the respondents, $35 \%$ believe that the situation in their municipality has improved since 1990, while 57\% report a deterioration. Concerns about economic development were mentioned by $70 \%$ of respondents. $47 \%$ of respondents saw the future in the development of tourism, $35 \%$ in agriculture. The opening of the border with Austria is viewed positively by $31 \%$ of the population, but mostly in terms of freedom to travel and to get to know the neighbours. On the other hand, $73 \%$ of respondents do not see an economic benefit. Some residents point out the increase in prices due to the demand of Austrian visitors, others are simply disturbed by the movement of foreigners. Roughly the same thirds are divided into respondents who prefer nature protection over economic development, economic development over nature protection and who are willing to seek a reasonable compromise. Among the most frequent negative social phenomena, respondents state extreme indifference to social problems and interpersonal conflicts, while social pathologies are reported rather exceptionally. The historical cross-section is interesting, when the best period in terms of the state of the landscape is the period before 1938, the best period for economic development is the second half of the socialist period, while the development of services occurs mainly after 1990.

This survey took place a quarter of a century ago, and the specific answers today would probably be different. However, if we want to deduce from the survey the consideration of the mental character of local residents, we can use a comparison with the other half of the territory observed in the survey at the time (the Jemnice area which also belongs to the rural peripheries, but is not located directly on the border and was less affected by the post-war population exchange). This comparison shows greater passivity and pessimism of the inhabitants of the Vranov region, less confidence in future development and lower stability towards migration. 


\subsection{Environmental Development}

Areas with a low population density are generally considered to be environmentally friendly with a low degree of anthropogenic load. In our case, this impression is further enhanced by the presence of the Podyji National Park, located in the eastern tip of the studied area. However, the disadvantage of small and very small villages in rugged terrain is that it is not economically efficient to build a complete technical infrastructure in them, including those that are environmentally important, such as sewage connected to a wastewater treatment plant or planning to address heating.

In the case of the Vranov micro-region, the focus of the municipalities near the Vranov water reservoir on recreation plays a role. Therefore, the villages near the Dyje river are fully equipped. However, municipalities with $20 \%$ of the region's population do not have a sewerage system connected to the wastewater treatment plant, $13 \%$ of the population lives in municipalities not connected to the public water supply and $15 \%$ of the population lives in municipalities that are not gasified. However, the technical equipment is relatively good in comparison with other areas. In the national average, $60 \%$ of municipalities under 1,000 inhabitants are not gasified, $64 \%$ are not connected with water treatment plants and $10 \%$ do not have public water supply. These residents address their needs individually (wells, domestic sewage treatment plants or septic tanks, solid fuels or electricity). In some cases, a negative effect on the environment cannot be completely ruled out. However, despite relatively high gasification, $61.5 \%$ of households still use solid fuels for heating (probably for financial reasons $-51 \%$ nationwide). This fact can probably be described as the main environmental problem in the winter - especially in municipalities in narrow basins. However, it is true that the data from the census are almost 10 years old and since then, there may have been a shift in heating technology).

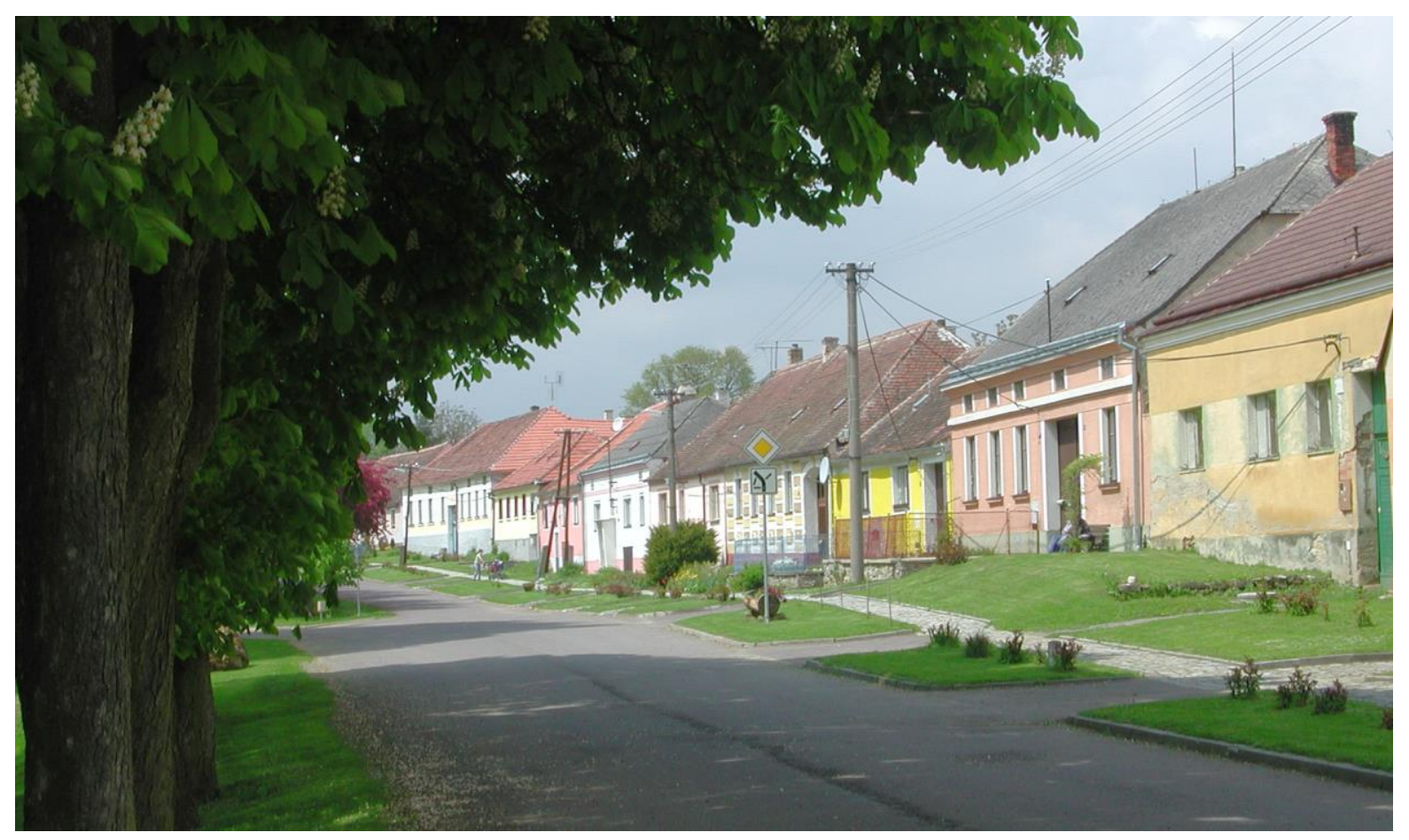

Fig 7. Vratěnín - rural memorial zone, Czech village of the year 1996. Photo authors

Another problem that potentially endangers the environment is the waste that is generated in the summer season in connection with recreation of the Vranov reservoir. The water quality at the Vranov beach itself is very good. In the summer season 2020, it was classified as suitable for swimming in all measurements ${ }^{8}$. The situation at Bítov beach is less favourable, but the water quality is not regularly monitored by the hygienic service there due to lower attendance.

\footnotetext{
${ }^{8}$ Brno: Regional hygienic station for the South-Moravian Region.
} 


\subsection{Pros and cons for future development}

An analysis of strengths and weaknesses, opportunities and threats, which are a standard part of the SWOT analysis, was used to assess the overall advantages and disadvantages for the development of the micro-region (Table 1). Strengths and weaknesses are an objective consequence of the geographical location of the historical development and their more significant changes cannot be expected in the near future. Opportunities and threats come from outside and cannot be influenced by the forces of the micro-region.

Tab 1. Strengths, weaknesses, occasions and threats based on the above analysis.

\begin{tabular}{|c|c|}
\hline $\begin{array}{l}\text { Strengths } \\
\text { - relatively preserved natural } \\
\text { environment } \\
\text { - favourable conditions for } \\
\text { the development of cultural and } \\
\text { recreational tourism }\end{array}$ & $\begin{array}{l}\text { Weaknesses } \\
\text { - } \text { remote location for economic } \\
\text { development } \\
\text { - } \text { weak human capital } \\
\text { - } \text { small villages with insufficient } \\
\text { infrastructure }\end{array}$ \\
\hline $\begin{array}{l}\text { Occasions } \\
\text { - transition towards the post-productive } \\
\text { society with increased role of tourism } \\
\text { and environment } \\
\text { - collaboration among communes } \\
\text { - European and national cohesion } \\
\text { policy }\end{array}$ & $\begin{array}{l}\text { Threats } \\
\text { - deepening interregional differences, } \\
\text { lagging periphery }\end{array}$ \\
\hline
\end{tabular}

In these circumstances, it is difficult to consider offensive strategies, because the opportunities are rather potential and the question is to what extent they could be used by a micro-region with the existing social and settlement structure. Therefore, we propose a so-called MAX-MIN (or also ST) strategy, which can be defined as the use of strengths to reduce threats. In practice, this means using favourable conditions for the development of quality housing in quality environmental conditions combined with cultural tourism and recreational tourism in order to limit the possible deepening of marginalization. Production should be focused on the green economy in small and medium-sized enterprises.

\section{Discussion: Rural Development}

The basic question for the overall assessment of sustainable development is the concept of development and the setting of indicators. In a liberal capitalist economy, development is often associated with quantitative growth, although since the 1960s, there have been voices warning against this concept. Indicators for the evaluation of development also derive from the idea of quantitative growth. It is obvious that extremely peripheral regions such as the Vranov region cannot succeed in this concept. However, if we turn our attention to the qualitative concept of development, the weights of the indicators will change. Some ideas of qualitative development are hidden in the concept of neo-rurality (Orria and Luise, 2017). However, the qualitative rural development is understood more in connection with the quality of the tourist destinations, very little as the quality of life of local residents (Vaishar, Vidovićová and Figueiredo, 2018).

In the context of the qualitative rural development, we can talk about rural sustainability. Sustainability is often understood as environmental sustainability (Mihai and latu, 2020) precisely in response to the unsustainability of a purely liberal model of development. However, it might be better to combine rural sustainability with its qualitative development. This is because, in the case of rural areas, the social pillar of sustainability is often at stake. In addition to the usual pillars of sustainability - environmental, economic and social, in the case of rural areas, there is also the sustainability of rural character in relation to urbanization. 


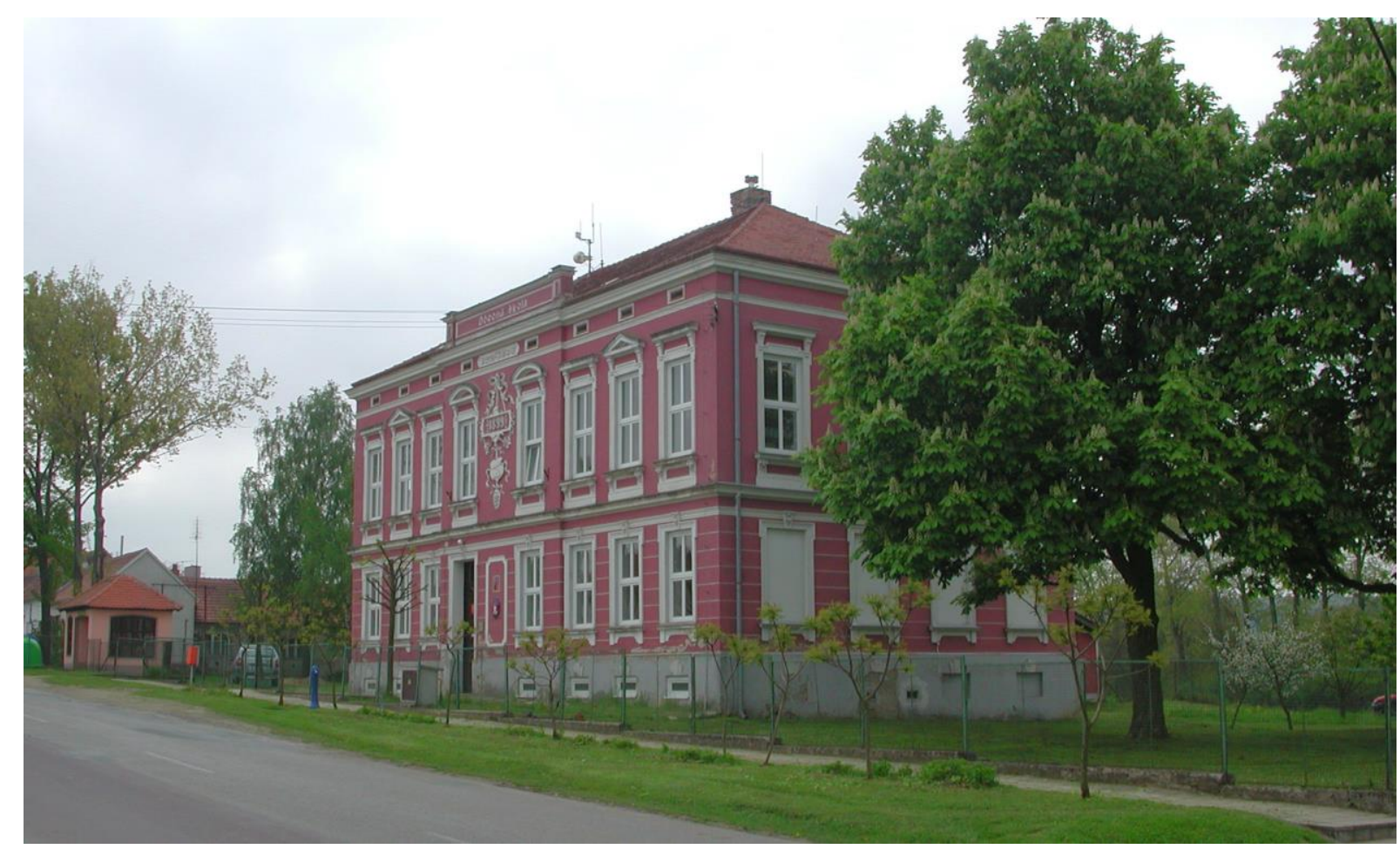

Fig 8. The school in Štitary, the second largest village in the area. Photo author

Another question is development for whom we mean. This is approached by the subjective perception of development by residents, entrepreneurs, visitors. This can be very different. Among other things, the aging of the population plays an important role (Skinner and Winterton, 2018). Seniors living on pensions and social benefits are generally not interested in economic development, but prefer conservative values. If we consider the migration balance as an indicator of the perception of rural development, we can state that it has been catching up recently. It is important to note that migration declines are typical especially for larger settlements. This could be interpreted as meaning that people looking for a peaceful atmosphere close to nature move to small villages, while people looking for access to services and a social atmosphere do not stay in medium-sized villages, but rather move to larger settlements. However, the reason may also be simpler, namely land that is cheaply available in the smallest settlements.

Entrepreneurs may have other ideas about development. According to a survey in $2014^{9}$, entrepreneurs see the following main barriers to their activities: too much administration and regulation, lack of investment funds, lack of quality employees, problems of technical infrastructure. They would welcome better promotion of the micro-region, joint problem-solving in municipalities, financial assistance for investment activities, training to obtain grants and subsidies.

Gradual development towards a post-productive society (Almsted et al., 2014) is changing the countryside from a space for production (food, energy) to a space for consumption (housing and recreation). In this respect, Vranov micro-region with less disturbed milieu may have certain advantages. Let us therefore ask the question of how our area meets the requirements for housing and the development of tourism in the conditions of an aging population.

From this point of view, tourism is becoming a crucial economic sector (Villanueva-Álvaro, Mondéjar-Jiménez and Sáez-Martínez, 2017), which must be regulated so as not to exceed a reasonable intensity in the busiest places. However, it must be acknowledged that this area will be among the poorer - because this sector, which is also mostly aimed at domestic tourists, will not bring too much regional benefits. Cultural tourism in a micro-region can be based on a combination of historical and architectural heritage and preserved natural environment. Cultural

\footnotetext{
${ }^{9}$ Strategy of community-led local development for the territory of LAG Jemnicko for the period 2014-2020.
} 
tourism can be supported by recreational tourism tied to the Vranov reservoir and leisure tourism associated with second homes. The potential for interconnection with the Austrian side has so far been insufficiently used. It would be necessary to maintain maximum profits in the region, i.e. to involve local entrepreneurs as much as possible (despite the lack of local capital), to offer, in addition to optional trips, accommodation and packages of attractions of various types.

From the point of view of housing, it is appropriate to maintain a quality environment and, if possible, to complete or maintain the infrastructure (Dziekański, 2020). The problem of the inhabitants of small villages, endangered by social exclusion, should be solved by the development of online services, by increasing the internet literacy of seniors and by the development of community life. The broadband internet availability seems to be the crucial issue (Townsend et al., 2017). These are tasks that are very difficult to accomplish with the existing human capital available. Given the high proportion of cottagers, it would be possible to seek some potential by involving the social capital of their owners (often of higher social status) in the development of rural communities.

Rural development in the Czech Republic is derived from rural development in the European Union. Emphasis is placed on the LEADER program. The rural peripheries are mainly concerned with the policy towards economically and socially endangered areas within the Regional Development Strategy of the Czech Republic 2021+. This policy is intended to support small business and external investment. Public investment, transport services and civic amenities should be ensured here. Among the goals are the development of community life and the prevention of social exclusion.

An important issue is the management of micro-regional development. Individual small and very small municipalities do not have sufficient human neither financial capital. The centre of the Vranov nad Dyji micro-region does not have the character of a small town, but rather a seasonal resort. Its ability to integrate the area, especially its remote western part, is problematic. The regional authority, which is the closest superior body of state administration, is too far away, not only in a geometric sense. The only possibility is probably the cooperation of municipalities within their self-governing function.

The Association for the Development and Renewal of Municipalities in the Vranov region was established in 1998 and unites 21 municipalities. Its territory more or less overlaps with the microregion under our study. The declared goal of the Association is to strive for the renewal and development of local cultural and social traditions and lifestyles. This goal is somewhat problematic, as the original German population was displaced after World War II and new settlers have tried to create some tradition and lifestyle for the last 75 years. In fact, the Association focuses on promoting the Vranov region as a tourist destination. The biggest expense in his budget is the operation of the tourist information centre.

LEADER LAGs are a tool for cooperation at the micro-regional level in terms of endogeneous development (Bosworth et al., 2020). The territory of the micro-region is covered by the Local Action Group Jemnice Region. Its centre, the small town of Jemnice (population 4,000), is located in the neighbouring region of Vysočina. It can therefore be said that the cooperation of the municipalities of the Vranov region in their self-governing competence is directed differently than their administrative subordination. This situation is one of the consequences of disrespecting the historical border between Moravia and Bohemia in the creation of new regions in 2000 . Southwest Moravia was insensitively divided among three administrative regions: South-Moravian, South-Bohemian and Vysočina.

The basic vision for the LAG's territory lies in offering sufficient economic opportunities, civic amenities, a healthy and safe environment, and attractive leisure opportunities. Public services include quality public administration, healthcare, transport services, services for the elderly. In the economic sphere, it is about quality education, stable job opportunities, competitive entrepreneurs and developed tourism. Improving the technical infrastructure is focused on utilities, roads, public buildings and open spaces, leisure facilities. In the field of landscape and living environment, the LAG should strive to regenerate conditions for the development of leisure activities for young people, crime prevention, support for cultural and sporting events, protection against the negative impacts of road transport, competitive agriculture and forestry and increasing 
the ecological stability of the landscape. Many of these goals are very general, or not focused directly on the Vranov region. However, the strategy roughly corresponds to the qualitative vision of development.

\section{Conclusions}

Our work tried to analyse the development possibilities of one of the most remote micro-regions in Moravia on the basis of sustainability criteria. The analyses show the expected situation. Insufficient economic resources are combined with low human capital. This situation is partially offset by a quality natural environment. The potential of rural development in peripheral areas is often associated in the literature with the mobilization of human capital (Czapiewski and Janc, 2019). However, the quality of human capital is one of the weaknesses of the micro-region. The possibility of mobilizing social capital remains. The question is whether social capital is not limited by a practically complete interruption of local traditions 75 years ago.

However, the situation may not seem pessimistic. If we changed liberal-economic notions of development as continuous quantitative growth, we would see the possibilities of the micro-region in a different light. The problem is that even qualitative growth in today's society requires sufficient financial resources. At present, these resources are supplied externally within the framework of European and national cohesion policy. However, is this method sustainable in the long run? Subsidies should be focused on starting their own activities of the micro-region. Otherwise, such a micro-region will be kept in a state of constant backwardness looking always for subsidies.

A transition to a post-productive society can bring a solution. This can increase the importance of the preserved natural environment of remote areas - especially if they have significant tourist attractions. Part of the whole transition process is also the weakening of one-way migrations from rural to urban and periphery to metropolitan regions. Counter-urbanization tendencies are directed not only to the surroundings of large cities, but part of them also to the periphery. However, the peripherals must be ready to absorb these migrants. If there is not enough human capital in the micro-region, endogenous development must be based on social capital (King et al., 2019). In practice, it is about supporting community life and cooperation within and among individual villages. Although tourism alone cannot ensure the development of a micro-region, this sector is very promising in relation to current developments. Some aspects of distance can be partially compensated by the use of digital technologies within the concept of smart village (Vaishar and Št’astná, 2019).

The study of peripheral regions at the local level should be given the attention of researchers dealing with rural development, as this is where significant changes can be expected. Some of these micro-regions may continue to depopulate tendencies, while others may begin to prosper. The conditionalities and externalities of this development may enrich the theory of regional development in the present period.

The question is to what extent the situation of the Vranov region is specific and to what extent the findings can be applied to the Central European or European countryside. Ethnically, conditioned population change, the impact of the Iron Curtain or the transition to the market economy seem to be very specific conditions. However, in the long run, these are episodes. Rather, the transition from productive to post-productive development and the technological development of agriculture, transport, communication technologies among others, which is decisive for changes in rural development, are more important. These changes are common for the whole Europe and thus the knowledge can be transferable to other rural regions.

\section{Acknowledgement}

This paper is one of the results of the HORIZON 2020 project Social and innovative Platform On cultural Tourism and its potential towards deepening Europeanisation ${ }^{10}$, ID 870644, funding scheme Research and Innovation action, call H2020-SC6-TRANSFORMATIONS-2019.

\footnotetext{
${ }^{10}$ https://cordis.europa.eu/project/id/870644
} 
[1] Aarstad, J. \& Jakobsen, S. E. (2020). Norwegian Firms' Green and New Industry Strategies: A Dual Challenge. Sustainability 12, Art. 361. DOI: 10.3390/su12010361.

[2] Almsted, Å., Brouder, P., Karlsson, S. \& Lundmark, L. (2014). Beyond post-productivism: from rural policy discourse to rural diversity. European Countryside 6(4), 297-306. DOI: 10.2478/euco-2014-0016.

[3] Berg, J. \& Ihlström, J. (2019). The Importance of Public Transport for Mobility and Everyday Activities among Rural Residents. Social Sciences 8, Art. 58. DOI: 10.3390/socsci8020058.

[4] Bosworth, G., Price, L., Hakulinen, V. \& Marango, S. (2020). Rural Social Innovation and Neo-endogenous Rural Development. In Cejudo, E. \& Navarro, F., eds., Neoendogenous Development in European Rural Areas (pp. 21-32). Cham: Springer. DOI: 10.1007/9783-030-33463-5_2.

[5] Burneika, D., Daugirdas, V. \& Ubarevičiené, R. (2014). Migration as a factor of development of the depopulating areas in the East EU countries - the case of Lithuania. EUROPA XXI 27, 79-95. DOI: 10.7163/Eu21.2,14.27.6.

[6] Carson, D., Brouder, P. \& de la Barre, S. (2017). Communities and new development paths in the sparsely populated North. Journal of Rural and Community Development 12(2/3), 111.

[7] Carson, D. A., Carson, D. B. \& Lundmark, L., eds. (2017). Tourism, mobilities and development in sparsely populated areas. London: Routledge.

[8] Chmelař, R., Svobodová, H., Binek, J., Synková, K., Holeček, J., Galvasová, I. \& Hiess, J. (2013). Strategie rozvoje mikroregionu Vranovsko na období 2014-2020. Brno: GaREP.

[9] Copus, A. K. (2001). From core - periphery to polycentric development: concepts of spatial and aspatial peripherality. European Planning Studies 9(4), 539-552. DOI: $10.1080 / 713666491$.

[10] Czapiewski, K. \& Janc, K. (2019). Education, human capital and knowledge the paradigm shift and future scenarios on Polish rural areas. In Bański, J., ed., Three Decades of Transformation in the East-Central European Countryside (pp. 351-367). Cham: Springer. DOI: 10.1007/978-3-030-21237-7_16.

[11] Delgado Viñas, C. (2019). Depopulation processes in European rural areas: a case study of Cantabria (Spain). European Countryside 11(3), 341-369. DOI: 10.2478/euco-2019-0021.

[12] Demek, J. et al. (1987). Zeměpisný lexikon ČSR. Hory a nížiny. Praha: Academia.

[13] Diaz-Puente, J. M., Gallego Moreno, F. J. \& Zamorano, R. (2012). Training as a tool for community development. 25 years of experience in sparsely populated rural areas in Cuenca, Spain. Perspectives in Education 30(2), 12-21.

[14] Dziekański, P. (2020). Spatial diversity of infrastructure and its impact on the development process of rural communes in Eastern Poland in 2009-2018. Baltic Journal of Economic Studies, 6(5), 23-32. DOI: 10.30525/2256-0742/2020-6-5-23-32.

[15] Giordano, B. (2017). Exploring the role of the ERDF in regions with specific geographical features: islands, mountainous and sparsely populated areas. Regional Studies 5(6), 869879, DOI: $10.1080 / 00343404.2016 .1197387$.

[16] Historický lexikon obcí České republiky 1869-2011 (2015). Praha, Czech Statistical Office.

[17] King, B., Fielke, S., Bayne, K., Klerkx, L. \& Nettle, R. (2019). Navigating shades of social capital and trust to leverage opportunities for rural innovation, Journal of Rural Studies 68, 123-134. DOI: 10.1016/j.jrurstud.2019.02.003.

[18] Kubeš, J. (2011). Chatové oblasti České republiky. Geografický časopis 63(1), 53-68. 
[19] Kubeš, J. \& Chvojková, A. (2020). Back to peripheries based on remoteness. Human capital in the peripheral municipalities of South Bohemia. Journal of Rural Studies 79, 116-124. DOI: $10.1016 /$ j.jrurstud.2020.08.045.

[20] Leu, T. (2018). Tourism work among Sámi indigenous people: exploring its prevalence and role in sparsely populated areas of Sweden [PhD theses]. Umeå University.

[21] Le Tourneau, F.-M. (2020). Sparsely populated regions as a specific geographical environment. Journal of Rural Studies 75, 70-79. DOI: 10.1016/j.jrurstud.2019.12.012.

[22] Lundmark, L., Eduardsson, M. \& Karlsson, S. (2014). International migration, selfemployment and restructuring through tourism in sparsely populated areas. Scandinavian Journal of Hospitality and Tourism 14(4), 422-440. DOI: 10.1080/15022250.2014.967995.

[23] Manakou, A. (2018). The phenomenon of rural depopulation in the Swedish landscape: Turning the trends [PhD theses]. Karlshamn: Blekinge Institute of Technology.

[24] Marada, M., Chromý, P., Jančák, V. \& Havlíček, T. (2006). Space polarization and peripheral regions in Czechia. EUROPA XXI, 15, 29-34.

[25] Margaras, V. (2016). Sparsely populated and underpopulated areas. Luxembourg: European Parliament Research Service.

[26] Mihai, F.-C. \& latu, C. (2020). Sustainable rural development under Agenda 2030. In Bastante-Ceca, M. J., Fuentes-Bargues, J. L., Hufnagel, L., Mihai, F.-C. \& latu, C., eds., Sustainability Assessment in the $21^{\text {st }}$ Century (pp. 9-18). London: IntechOpen.

[27] Muravska, T., Aprāns, J., Dahr, A. (2016). Cohesion policy in the sparsely populated countries. In Piattoni, S., Polverari, L., eds., Handbook in Cohesion Policy in the EU (pp. 285301). Cheltenham: Edward Elgar.

[28] Orria, B. \& Luise, O. (2017). Innovation in rural development: "neo-rural" farmers branding local quality of food and territory. Italian Journal of Planning Practice 7(1), 125-153.

[29] Popjaková, D., Danieová, K. \& Valešková, M. (2018). Importance of migration and counterurbanization as factors of stabilization of the demographic situation of the peripheral regions - example of South Bohemia. Folia Geographica 60(2), 101-117.

[30] Sandow, E. (2008). Commuting behaviour in sparsely populated areas: evidence from northern Sweden. Journal of Transport Geography 16(1), 14-27. DOI: 10.1016/j.jtrangeo.2007.04.004.

[31] Skinner, M. W. \& Winterton, R. (2018). Interrogating the contested spaces for rural aging: implications for research, policy and practice. The Gerontologist 58(1), 15-25. DOI: $10.1093 /$ geront/gnx094.

[32] Sörvik, J., Teräs, J., Dubois, A. \& Pertoldi, M. (2019). Smart Specialisation in sparsely populated areas: challenges, opportunities and new openings. Regional Studies 53(7), 1070-1080. DOI: 10.1080/00343404.2018.1530752.

[33] Stepanova, N., Gritsenko, D., Gavrilyeva, T. \& Belokur, A. (2020). Sustainable development in sparsely populated territories: Case of the Russian Artic and Far East. Sustainability 12(6), Art. 2367. DOI: $10.3390 /$ su12062367.

[34] Svensson, E. (2009). Consuming Nature-Producing Heritage: Aspects on Conservation, Economical Growth and Community Participation in a Forested, Sparsely Populated Area in Sweden. International Journal of Heritage Studies 15(6), 540-559. DOI: 10.1080/13527250903210837.

[35] Syssner, J. \& Meijer, M. (2020). Innovative Planning in Rural, Depopulating Areas: Conditions, Capacities and Goals. In Hagen, A., Higdem, U., eds., Innovation in Public Planning (pp. 151-169). Cham: Palgrave Macmillan. DOI: 10.1007/978-3-030-461362_9. 
[36] Townsend, L., Wallace, C., Fairhurst, G. \& Anderson, A. (2017). Broadband and the creative industries in rural Scotland. Journal of Rural Studies 54, 451-458. DOI: 10.1016/j.jrurstud.2016.09.001.

[37] Vaishar, A., Kallabová, E. \& Zapletalová, J. (2000). Vranov nad Dyjí / Jemnice - region $v$ transformaci. Brno: Regiograph.

[38] Vaishar, A. \& Pavlů, A. (2018). Outmigration intentions of secondary school students from a rural micro-region in the Czech inner periphery: a case study of the Bystrice nad Pernštejnem area in the Vysočina region. Acta Universitatis Carolinae Geographica 53(1), 49-57. DOI: 10.14712/23361980.2018.5.

[39] Vaishar, A. \& Št'astná, M. (2019). Smart Village and Sustainability. Southern Moravia Case Study, European Countryside, 11(4), 651-660. DOI: 10.2478/euco-2019-0036.

[40] Vaishar, A., Vidovićová, L. \& Figueiredo, E. (2018). Quality of rural life. Editorial. European Countryside 10(2), 180-190. DOI: 10.2478/euco-2018-0011.

[41] Villanueva-Álvaro, J.-J., Mondéjar-Jiménez, J. \& Sáez-Martínez, F.-J. (2017). Rural tourism: development management and sustainability in rural establishments. Sustainability 9(5), Art. 818. DOI: $10.3390 /$ su9050818.

[42] Wilson, R. \& Copus, A. (2018). Services of general interest (SGI) in the Scottish sparsely populated areas (SPA): exemplar services [working paper]. Aberdeen: The James Hutton Institute.

[43] Wójcik, M., Dmochowska-Dudek, K., Jeziorska-Biel, P. \& Tobiasz-Lis, P. (2018). Understanding strategies for overcoming peripherality: a Polish experience of transition. Bulletin of Geography, Socio-economic Series 40, 173-192. DOI: 10.2478/bog.2018.0022. 